Journal of Bangladesh Academy of Sciences, Vol. 39, No. 1, 31-36, 2015

\title{
MICROBIOLOGICAL ANALYSIS OF RAW MILK, PASTEURIZED MILK AND YOGURT SAMPLES COLLECTED FROM DIFFERENT AREAS OF DHAKA CITY, BANGLADESH
}

\author{
TASMINA RAHMAN*, TANZIA AKON, IFTIKHARUN NESSA SHEULI AND \\ NAIMA HOQUE
}

Department of Microbiology, Stamford University Bangladesh, Dhaka-1217, Bangladesh

\begin{abstract}
A total of 300 different milk and yogurt samples were collected from Dhaka city and analyzed for total viable bacterial count (TVBC), total coliform count (TCC) and presence of several pathogens such as Escherichia coli, Salmonella spp., Shigella spp., Vibrio spp. and Listeria monocytogenes. Raw milk samples collected from Moghbazar area showed highest TVBC $(4.2 \times$ $\left.10^{6} \mathrm{cfu} / \mathrm{ml}\right)$ and samples from Mohammadpur area showed lowest count $\left(3.5 \times 10^{3} \mathrm{cfu} / \mathrm{ml}\right)$. All the pasteurized milk samples showed TVBC of $1.9 \times 10^{2}$ to $2.8 \times 10^{3} \mathrm{cfu} / \mathrm{ml}$, and TCC only in one sample Yogurt samples (open) collected from vendor showed TVBC of $9.1 \times 10^{3}$ to $8.2 \times 10^{7}$ $\mathrm{cfu} / \mathrm{ml}$, and TCC only in sample collected from Dhanmondi, Dhaka. The packed yogurt samples showed TVBC of $2.2 \times 10^{2}$ to $6.1 \times 10^{3} \mathrm{cfu} / \mathrm{ml}$, and TCC only in one sample. All the milk and yogurt samples were found contaminated with E. coli and Shigella-like species. Listeria monocytogenes was not detected in any of the samples studied.
\end{abstract}

Key words: Raw milk, Pasteurized milk, Yogurt, Listeria monocytogenes, Coliform

\section{INTRODUCTION}

Milk is considered to be an ideal food and supposed to contain proteins, fats, carbohydrates, vitamins and mineral salts. For this rich nutritional composition, bacteria can easily multiply in milk (Park et al. 2007). The consumption of milk and milk products in Bangladesh is very low compared to neighboring countries (BER 2007), however, several reports document the presence of food borne pathogens, like Escherichia spp., Listeria spp., Staphylococcus spp. and other pathogenic bacteria in the udder of the animal, collected milk, untreated milk and milk samples becomes threat to human health (Baird-Parker and Tompkin 2000, de Buyser et al. 2001). These data reflect the unsanitary condition of the collection centers and the negligence of hygienic rules during the milking and carrying of the raw milk as well. According to Bangladesh Standard and Testing Institute (BSTI), the pasteurized milk sample must not contain TVBC more than $2 \times 10^{4} \mathrm{cfu} / \mathrm{ml}$. The guideline also allows the presence of less than 10 $\mathrm{cfu} / \mathrm{ml}$ of coliform bacteria and $0 \mathrm{cfu} / \mathrm{ml}$ of fecal coliforms (BSTI 2002, Jay 2003).

\footnotetext{
*Corresponding author: <tasmina_mb@yahoo.com>.
} 
Another popular and demanding nutritious food is cultured milk or yogurt. It is a fermented food with preserve nutrient value in the milk with a characteristic fresh taste derived from the action of bacteria on all or part of the lactose to produce several organic acids (Tamine and Robinson 2004). If produces from untreated or contaminated milk samples, yogurt can pose some health hazard and are labile to contamination.

There are mainly three sources of contamination of milk and milk products: inside and outside of udder, from the surface of handling and storage equipments. Post pasteurization contamination has received most of the attention and is considered to be a factor, which limits shelf life in the majority of cases (Tekinsen et al. 2007). In Bangladesh, BSTI (The Bangladesh Standards and Testing Institution) compels some chemical and sanitary requirements for pasteurized milk and milk cream; however, no guidelines are available for UHT milk (Hassan et al. 2009). Although there is little milk pockets specially milk-vita, and some other established dairy farms where surplus milk is readily available in Bangladesh, this perishable product has never received particular attention in hygienic distribution to the consumers (Khan et al. 2008).

The objectives of the present study were to assess the bacteriological quality of milk and several milk product samples giving priority to detect the presence of several pathogenic bacteria like E. coli, Salmonella, Shigella-like species, Vibrio and Listeria monocytogenes.

\section{MATERIALS AND METHODS}

Twenty raw milk and 20 vendor's yogurt samples were collected from each of five selected area (Moghbazar, Siddeswari, Lalmatia, Dhanmondi and Mohammadpur) of Dhaka Metropolitan city (total of 200 samples). These areas have been selected as they are densely populated and several schools and colleges have been located around. Furthermore, 10 samples each of pasteurized milk and packed yogurt were also collected from each of 5 commercially available brands. Samples were chosen randomly from different super shops and local markets. Raw samples were collected in sterile flask, however, packed milk and yogurt samples were purchased as sealed pack by checking the valid expiry dates. Samples were transferred to the laboratory for quality testing within 30 minutes it was collected.

The samples were serially diluted up to $10^{-7}$. Standard plate count (SPC) method recommended for dairy products (APHA 1960) was followed for quantitative analysis of bacteria.

A volume of $10 \mathrm{ml}$ raw sample was inoculated in buffered peptone broth, selenite cystine broth, alkaline peptone broth for enrichment of Escherichia coli, Salmonella spp., Shigella spp. and Vibrio spp., respectively and incubated for 6 hours. After that, $0.1 \mathrm{ml}$ of enriched sample was spread over MacConkey agar, Salmonella-Shigella agar and 
Thiosulfate citrate bile Salt sucrose (TCBS) agar media and incubated at $37^{\circ} \mathrm{C}$. On the otherhand, $0.1 \mathrm{ml}$ raw sample was spread over Listeria identification media and incubated at $37^{\circ} \mathrm{C}$. Following incubation for 24 hours, typical colonies for each genus were considered as positive growth and microscopic observation of the isolated bacteria was done by Gram staining. Confirmation of the organisms was performed by different biochemical tests, such as Triple Sugar Iron (TSI) agar, catalase test, citrate utilization test, indole test, motility test, methyl red test, Voges Proskaur test and urease production test (Cappuccino and Sherman 1996).

\section{RESULTS AND DISCUSSION}

This study tested a total of 200 open vendor milk and milk products, 100 raw milk and 100 open yogurt, to assess microbiological quality of those milk products. The laboratory investigation confirms presence of coliform and other bacteria in milk samples. The count of tested milk products are presented in Table 1. The count of TVBC and coliform bacteria in raw milk were higher than the acceptable limit set by Bangladesh Standard Testing Institute (BSTI 2002). Previously published study in Sylhet Agricultural University area in Bangladesh (Ara et al. 2010) also found the presence of high number of total viable count and total coliform count in the raw milk of samples. This was found that in raw milk the average TVBC was highest in the samples collected from Moghbazar area and the coliform count was highest in the samples collected from Siddeswari area.

Table 1. Total bacterial counts $(\mathrm{cfu} / \mathrm{ml})$ and coliform counts $(\mathrm{cfu} / \mathrm{ml})$ in raw milk and open vendor yogurt samples.

\begin{tabular}{lcccc}
\hline \multirow{2}{*}{ Collection area } & \multicolumn{2}{c}{ Raw milk $(\mathrm{n}=100)$} & \multicolumn{2}{c}{ Open yogurt $(\mathrm{n}=100)$} \\
\cline { 2 - 5 } & $\begin{array}{c}\text { Average TVBC } \\
(\mathrm{cfu} / \mathrm{ml})\end{array}$ & $\begin{array}{c}\text { Average TCC } \\
(\mathrm{cfu} / \mathrm{ml})\end{array}$ & $\begin{array}{c}\text { Average TVBC } \\
(\mathrm{cfu} / \mathrm{ml})\end{array}$ & $\begin{array}{c}\text { Average TCC } \\
(\mathrm{cfu} / \mathrm{ml})\end{array}$ \\
\hline Moghbazar & $4.2 \times 10^{6}$ & $3.4 \times 10^{3}$ & $8.2 \times 10^{7}$ & 0 \\
Siddeswari & $5.2 \times 10^{5}$ & $4.1 \times 10^{3}$ & $3.1 \times 10^{6}$ & 0 \\
Mohammadpur & $3.5 \times 10^{3}$ & $2.5 \times 10^{1}$ & $9.1 \times 10^{3}$ & 0 \\
Lalmatia & $4.7 \times 10^{4}$ & $3.8 \times 10^{1}$ & $4.0 \times 10^{4}$ & 0 \\
Dhanmondi & $3.6 \times 10^{3}$ & $5.1 \times 10^{1}$ & $7.3 \times 10^{5}$ & $2.8 \times 10^{3}$ \\
\hline
\end{tabular}

As yogurt is a cultured food, presence of bacterial population is obvious and there is no specific acceptable limit of bacterial population for yogurt is available. However, presence of pathogenic bacteria or coliforms is not acceptable and presence of coliform is often used as a parameter of proper sanitary condition in different countries (Tamine and Robinson 2004). The entire open vendor yogurt samples showed a large number of heterotropic bacterial growth (Table 1). Highest growth was found in the sample collected from Moghbazar area but the sample collected from Dhanmondi area showed presence of coliform which was a critical point of concern. It is assumed that the 
competition and low $\mathrm{pH}$ acts as an inhibitory factor for bacterial growth. Similar result was reported that in available market curd in different countries like in Bangladesh (Chowdhury et al. 2011), Sudan (Haj et al. 2007) and Lahore (Khalid et al. 2008).

In this study, the authors identified bacteria in pasteurized milk as well, but the average TVBC in pasteurized milk was less than threshold level of BSTI. They detected coliform in only one commercial pasteurized milk brand sample, brand three, which is not acceptable as per BSTI guidelines (Table 2). Rizwan et al. (2011) observed the presence on Bacillus brevis in pasteurized milk sample and suggested the post pasteurization process. Choudhury (2008) also reported the presence of coliform in pasteurized milk samples. There can be several steps in pasteurized milk production like proper temperature maintaining, handling and post pasteurization processing that might introduce bacteria in milk.

Table 2. Total bacterial counts (cfu/ml) and coliform counts (cfu/ml) in pasteurized milk and packed yogurt samples.

\begin{tabular}{lcccc}
\hline \multirow{2}{*}{ Brand } & \multicolumn{2}{c}{ Pasteurized milk $(\mathrm{n}=50)$} & \multicolumn{2}{c}{ Packed yogurt $(\mathrm{n}=50)$} \\
\cline { 2 - 5 } & $\begin{array}{c}\text { Average TVBC } \\
(\mathrm{cfu} / \mathrm{ml})\end{array}$ & $\begin{array}{c}\text { Average TCC } \\
(\mathrm{cfu} / \mathrm{ml})\end{array}$ & $\begin{array}{c}\text { Average TVBC } \\
(\mathrm{cfu} / \mathrm{ml})\end{array}$ & $\begin{array}{c}\text { Average TCC } \\
(\mathrm{cfu} / \mathrm{ml})\end{array}$ \\
\hline 1 & $2.5 \times 10^{2}$ & 0 & $4.3 \times 10^{2}$ & 0 \\
2 & $2.4 \times 10^{2}$ & 0 & $2.2 \times 10^{2}$ & 0 \\
3 & $2.8 \times 10^{3}$ & $1.4 \times 10^{1}$ & $3.2 \times 10^{3}$ & 0 \\
4 & $6.1 \times 10^{2}$ & 0 & $5.2 \times 10^{2}$ & 0 \\
5 & $1.9 \times 10^{2}$ & 0 & $6.1 \times 10^{3}$ & 0 \\
\hline
\end{tabular}

The commercially packed yogurt samples were found to harbor low range of heterotrophic bacteria with the highest number of $3.2 \times 10^{3} \mathrm{cfu} / \mathrm{ml}$ without coliform bacteria.

Raw milk samples collected from five different areas were found to be contaminated with several pathogenic bacteria like Escherichia coli, Salmonella spp., Shigella species and Vibrio spp. (Table 3). Presence of any of these bacteria in food samples is not acceptable as they can cause food borne illness (Rahman et al. 2008). Similar data were collected from the open vendor yogurt samples. This reflected the poor sanitary measure and under processed food parameters. The scenario is better in case of pasteurized milk and packed yogurt sample. However, presence of E. coli and Shigella-like species indicated the lower quality food samples. A study of quality assessment of milk product pointed to the presence of E. coli and Listeria monocytogenes in tested samples (Cordano and Rocourt 2001). A fact of hope that, no sample was found to be contaminated with $L$. 
monocytogenes. This organism is a potential cause of food poisoning found in variety of milk and dairy products (Farber 2000).

Table 3. Presence of pathogenic bacteria in different milk samples.

\begin{tabular}{lcccc}
\hline \multirow{2}{*}{ Bacteria } & \multicolumn{4}{c}{ Number of samples contaminated with pathogenic bacteria } \\
\cline { 2 - 5 } & $\begin{array}{c}\text { Raw milk } \\
(\mathrm{n}=100)\end{array}$ & $\begin{array}{c}\text { Pasteurized milk } \\
(\mathrm{n}=50)\end{array}$ & $\begin{array}{c}\text { Vendor yogurt } \\
(\mathrm{n}=100)\end{array}$ & $\begin{array}{c}\text { Packed yogurt } \\
(\mathrm{n}=50)\end{array}$ \\
\hline E. coli & 52 & 5 & 15 & 3 \\
Salmonella spp. & 6 & 0 & 13 & 0 \\
Shigella-like species & 11 & 2 & 6 & 2 \\
Vibrio spp. & 1 & 0 & 1 & 0 \\
Listeria spp. & 0 & 0 & 0 & 0 \\
\hline
\end{tabular}

\section{CONCLUSION}

The laboratory investigation confirms that most of the raw milk and open vendor yogurt samples that have been tested were contaminated with huge load of heterotropic bacteria. Bacterial contamination of these products assumed to be originated from poor hygiene sense of the handler and improper processing, preservation and marketing strategy. These products usually are found to be sold in an open condition with less sanitary measure which can introduce contaminants into these products. On the contrary, the pasteurized milk and packed yogurt are sold in sealed packs and in sufficient sanitary conditions. These physical barriers are useful to prevent microbial contamination. However, few products exceeded the acceptable limit of bacteria which indicate the inadequate processing and packaging of these goods. Therefore, proper guidance and education for the processor, handler and consumer are necessary to maintain a consistent healthy life of consumer body.

\section{ACKNOWLEDGEMENT}

The authors thank the authorities of the Stamford University Bangladesh for providing laboratory facilities and financial support.

\section{REFERENCES}

APHA (American Public Health Association). 1960. Standard Methods for the Examination of Water and Waste Water (A. E. Eaton, L. S. Clesceri and A.E. Greenberg, eds.). American public health association, Maryland, United Book Press Inc.

Ara, A, M. J. Uddin, M. M. Rahman and S. Saha. 2010. Quality of raw milk consumed by residential people of Sylhet. Int. J. Biores. 1(6): 23-25.

Baird-Parker, T. C. and R. B. Tompkin. 2000. Risk and Microbiological criteria. In The Microbiological Safety and Quality of Foods (Vol II), Lund B, Baird-Parker TC, and Gould GW (eds). pp. 1852-1885, Aspen Publishers, Maryland. 
BER (Bangladesh Economic Review). 2007. Bangladesh Economic Review, Ministry Of Finance, The Government of Bangladesh, Dhaka.

BSTI (Bangladesh Standard and Testing Institute). 2002. BDS 1702: 2002. Bangladesh Standard: Specification for Pasteurized Milk. pp. 2-3, Bangladesh Standards and Testing Institution, Tejgaon Industrial Area, Dhaka.

Cappuccino, J. G. and N. Sherman. 1996. Microbiology- A Laboratory Manual. The Benjamin/Cummings Publishing Co., Inc., Menlo Park, California.

Choudhury, K. A. 2008. Physical and microbial qualities of raw milk collected from Bangladesh agricultural university dairy farm and the surrounding villages. Bangladesh J. Veterinary Medicine 6(2): 217-221.

Chowdhury, N. A., K. Paramanik and W. Zaman. 2011. Study on the quality assessment of curd (Dahi), locally available in Bangladesh market. World J. Dai. Food Sci. 6(1): 15-31.

Cordano, A. M. and J. Rocourt. 2001. Occurrence of Listeria monocytogenes in food in Chile. Int. J. Food Microbiol. 70: 175-178.

de Buyser, M. L., B. Dufour, M. Maire and V. Lafarge. 2001. Implication of milk and milk products in food-borne diseases in France and in different industrialized countries. Int. J. Food Microbiol. 67: 1-17.

Farber, J. M. 2000. Present situation in Canada regarding Listeria monocytogenes and ready-to-eat sea food products. Int. J. Food Microbiol. 62: 247-251.

Haj, M. H. M., O. A. O. E. Owni and I. E. M. E. Zubeir. 2007. Assessment of chemical and microbiological quality of stirred yoghurt in Khartoum state, Sudaan. Res. J. Ani. And Vet. Sci. 2: $56-60$

Hassan, A., I. Amjad and S. Mahmood. 2009. Microbiological and physicochemical analysis of different UHT milk available in local market. As. J. Food Ag-Ind. 2(03): 434-447.

Jay, J. M. 2003. Modern Food Microbiology. 4th Edition, First Indian Edition: 1996, Reprint: 2003, p. 447, CBS Publishers and Distributors, New Delhi.

Khalid, K., S. U. Rehman, M. A. Khan, F. Anwar and S. Bhadar. 2008. Physical and chemical quality appraisal of commercial yoghurt brands sold at Lahore. ARPN J. Agr. Bio. Sci. 3(3): 14-21.

Khan, M. T. G., M. A. Zinnah, M. P. Siddique, M. H. A. Rashid, M. A. Islam and K. A. Choudhury. 2008. Physical and microbial qualities of raw milk collected from Bangladesh agricultural university dairy farm and the surrounding villages. Bangladesh J. Veterinary Medicine 6(2): 217-221.

Park, Y. W., M. Juarez, M. Ramos and G. F. W. Haenlein. 2007. Physicochemical characteristics of goat and sheep milk. Small Rumin. Res. 68: 88-113.

Rahman, M. M., M. M. Rahman, S. M. Arafat, A. Rahman, M. Z. H. Khan and M. S. Rahman. 2008. Microbiological Quality Assessment of a Local Milk Product, Kwacha Golla, of Bangladesh. J. Korean Soc. Appl. Biol. Chem. 51(4): 251-257.

Rizwan, M., A. Pervez and J. Khan. 2011. Bacterial quality of raw and packed milk. Can J. Sci. Ind. Research. 2(2): 86-94.

Tamine, A. Y. and K. Robinson. 2004. Yoghurt Science and Technology. Published by Institute of Applied Science. pp: 32-56.

Tekinsen, K. K., M. Elmali and Z. Ulukanli. 2007. Microbiological quality of UHT milk consumed in Turkey. Internet J. Food Safety 7: 45-48. 